\title{
Tunisia: Financial System Stability Assessment
}

This paper was prepared based on the information available at the time it was completed on July 6,2012 . The views expressed in this document are those of the staff team and do not necessarily reflect the views of the government of Tunisia or the Executive Board of the IMF.

The policy of publication of staff reports and other documents by the IMF allows for the deletion of market-sensitive information.

Copies of this report are available to the public from

International Monetary Fund • Publication Services

$70019^{\text {th }}$ Street, N.W. $\bullet$ Washington, D.C. 20431

Telephone: (202) 623-7430 • Telefax: (202) 623-7201

E-mail: publications@imf.org Internet: http://www.imf.org

\section{International Monetary Fund Washington, D.C.}




\title{
INTERNATIONAL MONETARY FUND
}

\section{TUNISIA}

\section{Financial System Stability Assessment}

\section{Prepared by the Monetary and Capital Markets and Middle East \& Central Asia Departments}

\author{
Approved by José Viñals and Masood Ahmed
}

July 6, 2012

This Financial System Stability Assessment (FSSA) is based on the work of a joint International Monetary Fund-World Bank Financial Sector Assessment Program (FSAP) mission to Tunisia during January 11-25, 2012. The team's main findings are:

- The banking sector may face large recapitalization needs to cover past losses or if the economic situation worsens.

- The balance sheets of state-owned banks need to be restructured and their governance improved to ensure that they operate on a commercial basis.

- Bank supervision needs to be strengthened following several years of neglect. In particular, stricter regulatory and reporting requirements should be introduced and enforced, including with regard to loan classification, assets and collateral valuation and provisioning, and compliance with international best practices.

- Financial soundness indicators suffer from deficiencies and banking sector data should be improved as a matter of urgency.

- The CBT should develop an exit strategy to unwind its large liquidity support to banks.

- A comprehensive capital market reform should be implemented over time to support long-term investment.

- The authorities' commitment to the reform of the financial sector helped improve the assessment, and the CBT has already established a working group to monitor the implementation of the FSAP recommendations. The IMF is preparing a multi-year technical assistance (TA) program, aimed at strengthening banking supervision.

The FSAP team comprised Messrs. Elias Kazarian (Mission Chief, IMF), Cédric Mousset (Mission Chief, WB); Joseph Crowley, Laurence de l'Escaille, Romain Veyrune, and Ms. Georgia Albertin (all IMF); Messrs. Alain Degroide (IMF expert, NBB), François Germain (IMF expert, BDF), and John Biggs (IMF external expert); and Messrs. Pierre-Laurent Chatain, Laurent Gonnet, Olivier Hassler, and Anderson Caputo da Silva; and Ms. Caroline Cerruti (all WB); and Mr. Laurent Le Mouël and Ms. Alice Negre (both WB experts).

The main authors of this report are Elias Kazarian and Joseph Crowley, with input from other members of the FSAP team.

FSAP assessments are designed to assess the stability of the financial system as a whole and not that of individual institutions. They have been developed to help countries identify and remedy weaknesses in their financial sector structure, thereby enhancing their resilience to macroeconomic shocks and cross-border contagion. FSAP assessments do not cover risks that are specific to individual institutions, such as asset quality, operational or legal risks, or fraud. 


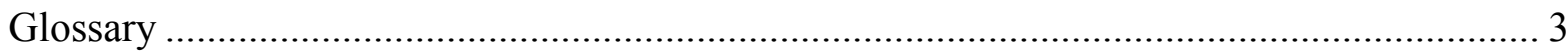

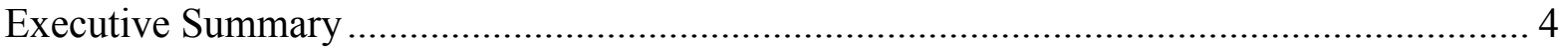

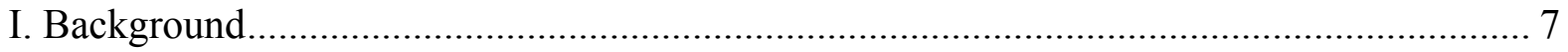

A. Political and Macroeconomic Outlook ………………............................................ 7

B. Implementation of 2006 FSAP Recommendations ........................................................ 7

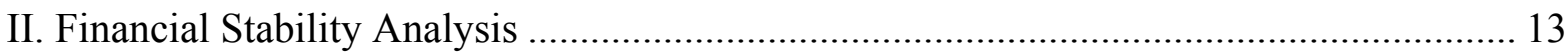

A. Financial System Structure …………..................................................................... 13

B. Banking System Vulnerabilities.............................................................................. 14

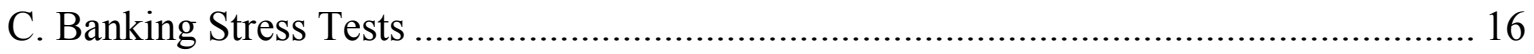

III. Banking Supervision and Financial Stability Arrangements .......................................... 20

A. Banking Regulation and Supervision...................................................................... 20

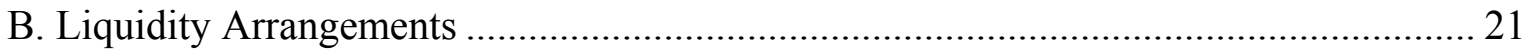

C. Crisis Management and Bank Resolution ................................................................. 22

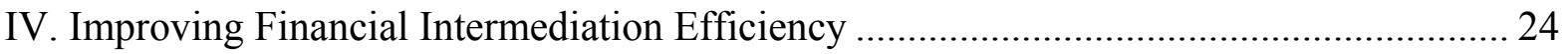

A. Industry Structure and Bank Competition …………................................................ 24

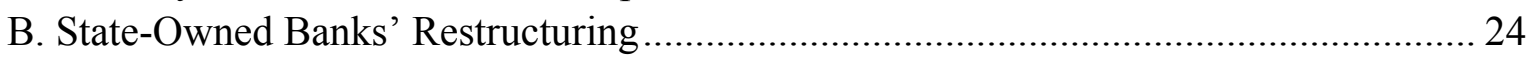

C. Small- and Medium-Sized Enterprise Finance........................................................... 25

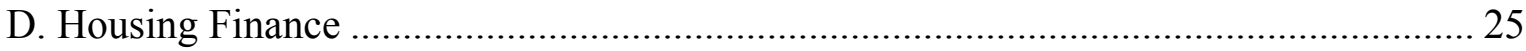

E. Capital Market Development ………………………........................................... 26

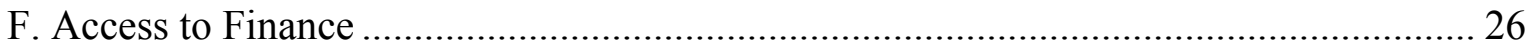

V. Anti-Money Laundering and Combating the Financing of Terrorism (AML/CFT).......... 27

Tables

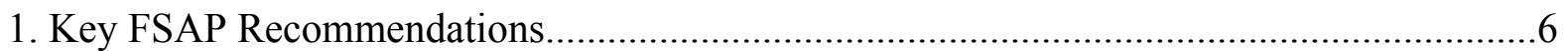

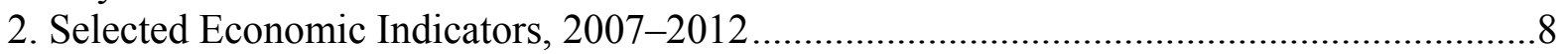

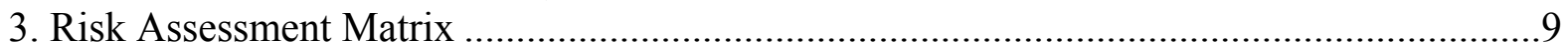

4. Implementation of 2006 Recommendations ................................................................11

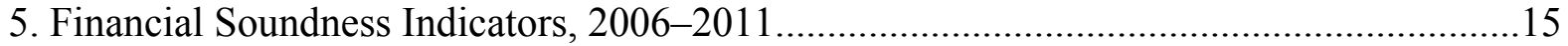

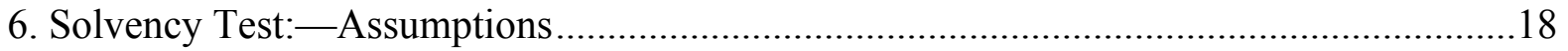

7. Liquidity Test:-Assumptions .......................................................................................19

Figures

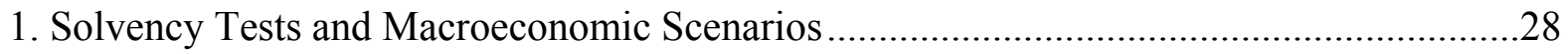

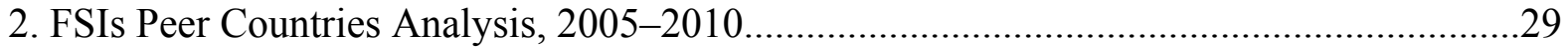




\section{GLOSSARY}

AML

BCP

CAR

CBT

CFT

CMA

$\mathrm{CNC}$

DAR

DIS

BSD

ELA

FATF

FDI

FSIs

FSAP

GDP

MOF

MOU

LTV

NBFI

NPL

OTC

RWA

ROA

ROSC

ROE

SRR

TN

TD

WEO
Anti-Money Laundering

Basel Core Principles for Effective Banking Supervision

Capital Adequacy Ratio

Central Bank of Tunisia

Combating the Financing of Terrorism

Capital Market Authority

National Accounting Board

Detailed Assessment Report

Deposit Insurance Scheme

Banking Supervision Department

Emergency Liquidity Assistance

Financial Action Task Force

Foreign Direct Investment

Financial Soundness Indicators

Financial Sector Assessment Program

Gross Domestic Product

Ministry of Finance

Memorandum of Understanding

Loan-to-Value

Non-Bank Financial Institutions

Nonperforming Loan

Over-the-Counter

Risk-Weighted Assets

Return on Assets

Report on Observance of Standards and Codes

Return on Equity

Special Resolution Regime

Technical Note

Tunisian Dinar

World Economic Outlook 


\section{EXECUTIVE SUMMARY}

The banking sector faces significant challenges owing to a weak domestic economy, and from the legacy of the previous regime. In particular, loan quality, solvency, and profitability have deteriorated, and weaknesses in underwriting had led to inappropriate lending to well-connected borrowers. Moreover, weakness in supervisory reporting and data provision mean that vulnerabilities could be much higher than reported. The mission urged the authorities to address the serious weaknesses in data management, including by creating a uniform database and standardized template to allow frequent and broad bank-by-bank performance monitoring.

Against this background the mission urged preemptive action to raise bank capital. The team estimated that to cover existing weaknesses in loan quality and potential future losses, including those related to under-reporting, the system as a whole could require additional capital in an amount exceeding 5 percent of GDP. To assist in this process, the authorities are encouraged to increase the minimum capital adequacy ratio (CAR) from 8 percent to 10 percent by 2014, and to impose higher solvency requirements on those banks with a higher risk profile.

Starting from an extremely weak position, the CBT has recently made commendable strides in strengthening banking supervision. A medium-term plan to build effective banking supervision was initiated in February 2012, including a new organization, and reassignment and recruitment of staff. The CBT also adopted a new corporate governance regime for commercial banks to increase the role and independence of their boards.

Nonetheless, bank supervision and regulation fall well short of international best practice and need significant further strengthening. The supervisory response to the recent challenges has been hampered by extremely weak capacity and outdated practices. Full on-site inspections have not been held since 2006, and should be conducted urgently first with all major banks. The CBT should also require banks to apply international best practices for loss reporting, collateral valuation and classification, and provisioning of nonperforming loans (NPLs). Furthermore, the CBT needs to strengthen its enforcement regime, establish clear conflict-of-interest policies for its staff, and increase its transparency and accountability.

The current circumstances provide an opportunity to revisit the rationale for and the modes of state intervention. Public banks have been used to support nonviable state-owned enterprises and activities, their governance arrangements have been weak, and they have been staffed mainly with civil servants with no banking experience. In addition to addressing these issues, the major state-owned banks should be subject to in-depth audits by international firms, including assessments of their viability if significant recapitalization needs are identified. 
Crisis-management arrangements need to be developed. In the past, distressed institutions have not been required to restructure or exit the market. Going forward, a special bank resolution regime and preparation for an eventual deposit insurance scheme are needed in order to facilitate an orderly structural change in the sector.

The CBT should develop an exit strategy to unwind gradually its large liquidity support to banks. Liquidity injections in 2011 supported strong credit growth but significantly increased the credit exposure of the central bank and led to a significant decline of foreign reserves. This strategy should be implemented gradually in order to allow banks time to adjust their funding needs and enhance the functioning of the interbank market.

A comprehensive capital market reform is needed to support long-term investment. The Capital Market Authority (CMA) needs to strengthen its oversight of investment markets. A reliable yield curve should be developed, and the confiscated assets of the old regime could be sold to jumpstart markets.

Banking sector reform should improve access to finance for individuals, and small and medium enterprises (SMEs). This should be supplemented by swift implementation of the 2011 microfinance law and integration of microfinance institutions into the national payment infrastructure through partnerships with other financial institutions.

The authorities' commitment to reform enhanced the ability of the FSAP team to conduct its assessment. Encouragingly, the CBT has already established a working group, comprised key financial sector stakeholders, to monitor the implementation of the 2012 FSAP recommendations.

The IMF is preparing a multi-year technical assistance (TA) program, aimed mainly at strengthening banking supervision. 
Table 1. Tunisia: Key FSAP Recommendations

\begin{tabular}{|c|c|c|}
\hline Recommendations & Priority & Timeframe $^{1}$ \\
\hline \multicolumn{3}{|l|}{ Bank supervision } \\
\hline $\begin{array}{l}\text { Ensure appropriate independence of the supervisor, including regarding } \\
\text { appointment and dismissal of senior officials (para 30). }\end{array}$ & High & Short term \\
\hline $\begin{array}{l}\text { Significantly increase resources, including hiring staff with banking and market } \\
\text { experience (para 26). }\end{array}$ & High & Short term \\
\hline Conduct in-depth on-site inspections starting with the largest banks (para 28). & High & Short term \\
\hline $\begin{array}{l}\text { Apply international standards for loan classification, provisioning, and valuation } \\
\text { of collateral (paras 12-14). }\end{array}$ & High & Short term \\
\hline $\begin{array}{l}\text { Address the serious weaknesses in data management by enhancing the } \\
\text { collection and processing of bank data, and creating a uniform database and } \\
\text { standardized template (para 12). }\end{array}$ & High & Short term \\
\hline $\begin{array}{l}\text { Increase the minimum CAR to } 10 \text { percent by } 2014 \text { and to } 12 \text { percent by } 2016 \text {, } \\
\text { and increase the Tier } 1 \text { ratio to } 7 \text { percent by } 2016 \text { (para 29). }\end{array}$ & High & Medium term \\
\hline \multicolumn{3}{|l|}{ Bank restructuring } \\
\hline $\begin{array}{l}\text { Conduct an in-depth independent assessment of the balance sheets of the } \\
\text { three large state-owned banks, and develop a strategy for ensuring they } \\
\text { operate on a commercially oriented basis (para 48-49). }\end{array}$ & High & Short term \\
\hline $\begin{array}{l}\text { Develop strategy to limit state ownership of banks to cases of clear public } \\
\text { policy need (para 49). }\end{array}$ & Medium & Medium term \\
\hline $\begin{array}{l}\text { Ensure that the same rules and regulations, including those related to } \\
\text { governance structure, apply to state-owned banks and private banks (para } 30 \\
\text { and 48). }\end{array}$ & Medium & Medium term \\
\hline \multicolumn{3}{|l|}{ Crisis management and bank resolution } \\
\hline $\begin{array}{l}\text { Develop a crisis-management framework and a special bank resolution regime } \\
\text { (paras 38-39). }\end{array}$ & High & Short term \\
\hline $\begin{array}{l}\text { Revise the lender-of-last-resort framework to give explicit power to the CBT to } \\
\text { advance funds, secured by adequate collateral, to solvent but illiquid banks } \\
\text { (para 43). }\end{array}$ & Medium & Medium term \\
\hline \multicolumn{3}{|l|}{ Systemic Liquidity } \\
\hline Introduce a haircut on all collateral used for refinancing operations (para 35). & Medium & Short term \\
\hline $\begin{array}{l}\text { Consider asking banks to pledge only treasury bonds as collateral for regular } \\
\text { central bank liquidity provision (para } 35 \text { ). }\end{array}$ & Medium & Medium term \\
\hline $\begin{array}{l}\text { The CBT should increase gradually the cost of banks' refinancing from the } \\
\text { central bank in order to unwind CBT liquidity support to banks (para 35). }\end{array}$ & Medium & Medium term \\
\hline \multicolumn{3}{|l|}{ Nonbank financial institutions } \\
\hline $\begin{array}{l}\text { Reform the sovereign bond market to create a benchmark for pricing fixed- } \\
\text { income products (para 55). }\end{array}$ & Medium & Short term \\
\hline $\begin{array}{l}\text { Consider offering some confiscated assets and state-owned enterprises (as } \\
\text { part of privatization programs) to the public (para 55). }\end{array}$ & Medium & Medium term \\
\hline Step up CMA supervision (para 56). & Medium & Short term \\
\hline
\end{tabular}




\section{BACKGROUND}

\section{A. Political and Macroeconomic Outlook}

1. Tunisia has stabilized following a major political transformation, but uncertainties remain. Following successful democratic elections for a Constituent Assembly in October, a new interim-government was confirmed by the assembly in December 2011. The new government's priorities include establishing transparent and participatory governance, tackling high unemployment, supporting private investment, and developing the disadvantaged regions of the interior.

2. Real GDP is estimated to have contracted by 1.8 percent in 2011 (Table 2). Economic activity in Tunisia was severely affected in 2011 by domestic events as well as the conflict in neighboring Libya. Tourism receipts dropped by 30 percent and FDI fell also by about 25 percent. The economic downturn and the return of Tunisian workers from Libya helped push the unemployment rate to 19 percent, with the youth unemployment rate reaching 42 percent.

3. CBT liquidity support contributed to rapid credit growth and an uptick in inflation. The credit-to-GDP ratio increased from 60 percent in 2007 to almost 70 percent in 2011 - having been stagnant for almost a decade - supported by CBT refinancing. Indeed, the CBT's exposure to the banking system increased to about 25 percent of its assets by end-2011, up from 2.5 percent at end-2010. In 2011, average headline inflation remained moderate at 3.5 percent but non-administered prices increased by about 6 percent, and headline inflation reached 5.7 percent in April 2012.

4. The Tunisian economy is expected to recover gradually in 2012, but significant downside risks remain that may impact the financial sector. Real growth is projected to reach about 2 percent in 2012, supported by a gradual rebound in tourism and FDI as well as a sizable fiscal stimulus. However, this recovery would leave growth well below the 4 percent to 5 percent average during the 2000s, and would be subject several risks, including a worsening of the recession in Europe; protracted instability in Libya; political uncertainty; and financing constraints affecting the execution of the envisaged fiscal stimulus (Table 3).

\section{B. Implementation of 2006 FSAP Recommendations}

5. The core recommendations of the 2006 FSAP were not implemented. These recommendations centered on: the proposed comprehensive reform of the state-owned banks to improve their risk management; addressing the overhang of nonperforming loans; and the rationalization of staffing and duties (Table 4). 
Table 2. Tunisia: Selected Economic Indicators, 2008-2017

\begin{tabular}{|c|c|c|c|c|c|c|c|c|c|c|}
\hline & \multirow[b]{2}{*}{2008} & \multirow[b]{2}{*}{2009} & \multirow[b]{2}{*}{2010} & \multirow{2}{*}{$\frac{\text { Est. }}{2011}$} & \multicolumn{6}{|c|}{ Projections } \\
\hline & & & & & 2012 & 2013 & 2014 & 2015 & 2016 & 2017 \\
\hline \multicolumn{11}{|l|}{ Production and income (percent change) } \\
\hline Nominal GDP & 10.9 & 6.3 & 7.8 & 2.2 & 8.6 & 8.2 & 7.7 & 8.5 & 8.6 & 9.4 \\
\hline Real GDP & 4.5 & 3.1 & 3.0 & -1.8 & 2.7 & 3.5 & 4.1 & 5.3 & 5.5 & 6.0 \\
\hline GDP deflator & 6.1 & 3.1 & 4.7 & 4.1 & 5.8 & 4.6 & 3.5 & 3.0 & 2.9 & 3.2 \\
\hline Consumer price index $(\mathrm{CPI})$, average & 4.9 & 3.5 & 4.4 & 3.5 & 5.0 & 4.0 & 3.5 & 3.5 & 3.5 & 3.5 \\
\hline Gross national savings (in percent of GDP) & 22.1 & 21.9 & 21.6 & 16.8 & 18.1 & 18.9 & 20.1 & 21.0 & 21.9 & 22.8 \\
\hline Gross investment (in percent of GDP) & 25.9 & 24.8 & 26.4 & 24.1 & 25.1 & 25.9 & 26.2 & 26.5 & 26.7 & 27.0 \\
\hline \multicolumn{11}{|l|}{ External sector (percent change) } \\
\hline Exports of goods, f.o.b. (in \$) & 26.6 & -24.8 & 14.0 & 8.5 & 0.9 & 5.3 & 7.5 & 9.3 & 9.8 & 10.6 \\
\hline Imports of goods, f.o.b. (in \$) & 28.7 & -21.9 & 15.9 & 7.7 & 2.2 & 5.6 & 5.2 & 6.7 & 7.3 & 8.3 \\
\hline Exports of goods, f.o.b. (volume) & 5.5 & -9.6 & 6.7 & -1.5 & -1.5 & 4.8 & 7.7 & 9.7 & 9.3 & 9.6 \\
\hline Import of goods, f.o.b. (volume) & 7.3 & 1.0 & -1.8 & -6.0 & 5.0 & 6.5 & 7.0 & 7.9 & 7.8 & 8.3 \\
\hline Trade balance (in percent of GDP) & -8.9 & -8.5 & -10.3 & -10.4 & -11.1 & -11.4 & -10.7 & -9.8 & -9.0 & -8.2 \\
\hline Current account, excluding grants (in percent of GDP) & -3.8 & -2.8 & -4.8 & -7.3 & -7.0 & -6.9 & -6.2 & -5.5 & -4.8 & -4.2 \\
\hline Foreign direct investment (percent of GDP) & 5.7 & 3.3 & 3.0 & 0.9 & 2.5 & 2.8 & 3.2 & 3.7 & 4.2 & 4.6 \\
\hline Terms of trade (deterioration -) & 0.1 & 7.6 & -9.6 & -4.0 & 5.1 & 1.4 & 0.5 & 0.0 & 3.7 & 4.0 \\
\hline Real effective exchange rate (depreciation -) 1/ & -0.7 & -1.1 & -0.5 & -1.8 & $\ldots$ & $\ldots$ & $\ldots$ & $\ldots$ & $\ldots$ & $\ldots$ \\
\hline \multicolumn{11}{|l|}{$\begin{array}{l}\text { Central government (percent of GDP, unless } \\
\text { otherwise indicated) } 2 /\end{array}$} \\
\hline Total revenue, excluding grants and privatization & 23.8 & 22.8 & 22.8 & 24.5 & 23.8 & 23.0 & 23.1 & 23.2 & 23.5 & 23.7 \\
\hline Total expenditure and net lending & 24.8 & 25.8 & 23.9 & 28.2 & 30.8 & 28.1 & 27.2 & 26.5 & 26.1 & 25.7 \\
\hline $\begin{array}{l}\text { Central government balance, excluding grants and } \\
\text { privatization }\end{array}$ & -1.0 & -3.0 & -1.1 & -3.7 & -7.0 & -5.1 & -4.0 & -3.4 & -2.6 & -2.0 \\
\hline Central government balance, including grants, & & & & & & & & & & \\
\hline excluding privatization & -0.7 & -2.7 & -1.0 & -3.4 & -6.4 & -5.0 & -3.9 & -3.3 & -2.5 & -1.9 \\
\hline Total government debt (foreign and domestic) & 43.3 & 42.8 & 40.4 & 44.4 & 45.7 & 50.5 & 50.7 & 49.9 & 48.7 & 46.4 \\
\hline Foreign currency public debt (percent of total debt) & 60.8 & 58.5 & 60.7 & 58.0 & 61.4 & 58.5 & 59.5 & 59.7 & 60.3 & 61.5 \\
\hline \multicolumn{11}{|l|}{ Money and credit (percent change) } \\
\hline Credit to the economy & 14.0 & 10.3 & 19.6 & 13.5 & 5.7 & $\ldots$ & $\ldots$ & $\ldots$ & $\ldots$ & $\ldots$ \\
\hline Broad money (M3) 3/ & 14.4 & 13.0 & 12.1 & 9.2 & 10.8 & $\ldots$ & $\ldots$ & $\ldots$ & $\ldots$ & $\ldots$ \\
\hline Liquidity aggregate (M4) & 14.2 & 12.7 & 12.2 & 9.2 & 10.8 & $\ldots$ & $\ldots$ & $\ldots$ & $\ldots$ & $\ldots$ \\
\hline Velocity of circulation (GDP/M3) & 1.62 & 1.52 & 1.46 & 1.37 & 1.34 & $\ldots$ & $\ldots$ & $\ldots$ & $\ldots$ & $\ldots$ \\
\hline Interest rate (money market rate, in percent, e.o.p) 4/ & 4.90 & 4.10 & 4.12 & 3.05 & $\ldots$ & $\ldots$ & $\ldots$ & $\ldots$ & $\ldots$ & $\ldots$ \\
\hline \multicolumn{11}{|l|}{ Official reserves } \\
\hline Gross official reserves (US\$ billions, e.o.p) & 9.0 & 10.6 & 9.5 & 7.5 & 8.2 & 8.7 & 9.4 & 10.4 & 11.7 & 13.5 \\
\hline In months of imports of goods and services, c.i.f. 5/ & 4.4 & 6.6 & 5.1 & 3.8 & 4.0 & 4.0 & 4.2 & 4.3 & 4.5 & 4.8 \\
\hline \multicolumn{11}{|l|}{ Total external debt } \\
\hline External debt (US\$ billions) & 20.6 & 21.5 & 21.4 & 22.0 & 24.2 & 26.1 & 27.7 & 29.1 & 30.2 & 31.3 \\
\hline External debt (in percent of GDP) & 48.8 & 48.2 & 48.5 & 51.0 & 53.7 & 55.8 & 56.9 & 56.9 & 56.1 & 54.8 \\
\hline Debt service ratio (percent of exports of GNFS) & 8.6 & 11.9 & 10.5 & 11.7 & 10.4 & 9.8 & 9.1 & 8.5 & 7.6 & 6.8 \\
\hline \multicolumn{11}{|l|}{ Financial market indicators } \\
\hline Stock market index 6/ & 2,892 & 4,292 & 5,113 & 4,722 & $\cdots$ & $\cdots$ & $\cdots$ & $\cdots$ & $\cdots$ & $\cdots$ \\
\hline \multicolumn{11}{|l|}{ Memorandum items: } \\
\hline GDP at current prices (TD millions) & 55,296 & 58,768 & 63,380 & 64,802 & 70,402 & 76,182 & 82,053 & 89,027 & 96,684 & 105,787 \\
\hline GDP at current prices (US\$ billions) & 44.9 & 43.5 & 44.3 & 46.0 & 46.1 & 48.0 & 49.9 & 52.4 & 55.1 & 58.5 \\
\hline GDP per capita (US\$) & 4,346 & 4,171 & 4,199 & 4,320 & 4,284 & 4,409 & 4,542 & 4,715 & 4,909 & 5,156 \\
\hline Unemployment rate (in percent) $7 /$ & 12.6 & 13.3 & 13.0 & 18.9 & $\ldots$ & $\ldots$ & $\ldots$ & $\ldots$ & $\ldots$ & $\ldots$ \\
\hline Population (millions) & 10.3 & 10.4 & 10.5 & 10.7 & 10.8 & 10.9 & 11.0 & 11.1 & 11.2 & 11.3 \\
\hline Exchange rate: dinar/US\$ (average) & 1.23 & 1.35 & 1.43 & 1.41 & $\ldots$ & $\ldots$ & $\ldots$ & $\ldots$ & $\ldots$ & $\ldots$ \\
\hline
\end{tabular}

Sources: Tunisian authorities; and IMF staff estimates and projections.

1/ Information Notice System.

2/ Excludes the social security accounts.

3/ Financial system (deposit money banks and development banks).

4/ 2011 data is the money market rate on 10/17/2011.

5/ End-of-year reserves over current year imports of goods and services.

6/ TUNINDEX $(1000=12 / 31 / 1997)$, with 2011 data at 10/17/2011.

7/ New series based on the ILO definition of the labor force. 
Table 3. Tunisia: Risk Assessment Matrix

\begin{tabular}{|c|c|c|}
\hline $\begin{array}{l}\text { Nature/Source of } \\
\text { Main Threats }\end{array}$ & $\begin{array}{c}\text { Likelihood of Severe Realization in } \\
\text { the Next Three Years }\end{array}$ & $\begin{array}{l}\text { Expected Impact on Financial } \\
\text { Stability if Threat is Realized }\end{array}$ \\
\hline $\begin{array}{l}\text { Worsening of the } \\
\text { recession in Europe }\end{array}$ & $\begin{array}{l}\text { Staff assessment: High } \\
\text { - Macroeconomic indicators and } \\
\text { IMF projections forecast negative } \\
\text { growth in the euro region for } \\
\text { 2012, with sizable downside } \\
\text { risks. }\end{array}$ & $\begin{array}{l}\text { Staff assessment: High } \\
\text { - Tunisia has significant economic } \\
\text { linkages with France and Italy } \\
\text { through tourism and exports, as } \\
\text { well as FDI inflows and } \\
\text { remittances. A worse-than- } \\
\text { expected recession in Europe } \\
\text { would significantly undermine } \\
\text { Tunisia's growth prospects } \\
\text { through trade and investment } \\
\text { channels. In turn, weaker-than- } \\
\text { expected economic growth could } \\
\text { adversely affect the stability of } \\
\text { the banking sector, leading to an } \\
\text { increase in NPLs. }\end{array}$ \\
\hline $\begin{array}{l}\text { Unidentified } \\
\text { weaknesses in the } \\
\text { banking sector }\end{array}$ & $\begin{array}{l}\text { Staff assessment: High } \\
\text { - Comprehensive inspections } \\
\text { have not been conducted since } \\
\text { 2006; weak external auditing, in } \\
\text { some cases, and banks lack } \\
\text { good information technology. } \\
\text { The CBT has a fragmented data } \\
\text { management system. }\end{array}$ & $\begin{array}{l}\text { Staff assessment: High } \\
\text { - A significant increase in } \\
\text { recorded NPLs, calling for higher } \\
\text { provisioning, which would lower } \\
\text { bank capital. }\end{array}$ \\
\hline $\begin{array}{l}\text { Continued loss of } \\
\text { external reserves }\end{array}$ & $\begin{array}{l}\text { Staff assessment: Medium } \\
\text { - The CBT has been providing } \\
\text { large amounts of liquidity to the } \\
\text { banks. This has been associated } \\
\text { with a widening of the current } \\
\text { account deficit a significant } \\
\text { decline in FDI inflows and loss of } \\
\text { reserves. }\end{array}$ & $\begin{array}{l}\text { Staff assessment: High } \\
\text { - If external reserves are } \\
\text { exhausted, the CBT might be } \\
\text { forced to stop providing liquidity } \\
\text { to banks, necessitating a } \\
\text { restructuring of banks with weak } \\
\text { loan portfolios or insufficient } \\
\text { liquidity. }\end{array}$ \\
\hline $\begin{array}{l}\text { Political instability and } \\
\text { heightening of social } \\
\text { tensions }\end{array}$ & $\begin{array}{l}\text { Staff assessment: Medium } \\
\text { - Tunisia successfully held its first } \\
\text { democratic general elections for } \\
\text { a constituent assembly, marking } \\
\text { a crucial step in the country's } \\
\text { orderly political transition to } \\
\text { democracy. However, the risk of } \\
\text { political instability and social } \\
\text { tensions remains. In particular, } \\
\text { widespread strikes and sit-ins } \\
\text { have continued to hamper } \\
\text { investment and industrial activity. }\end{array}$ & $\begin{array}{l}\text { Staff assessment: High } \\
\text { - Increased political instability and } \\
\text { heightened social tensions could } \\
\text { hamper domestic and foreign } \\
\text { investments, as well as tourism, } \\
\text { thus weakening Tunisia's growth } \\
\text { prospects. Weaker-than- } \\
\text { expected economic performance } \\
\text { could result in increased NPLs } \\
\text { and possible deposit } \\
\text { withdrawals, thus weakening the } \\
\text { stability of the financial sector. }\end{array}$ \\
\hline
\end{tabular}


Table 3. Tunisia: Risk Assessment Matrix (continued)

\begin{tabular}{|l|l|l|}
\hline \multicolumn{1}{|c|}{$\begin{array}{c}\text { Nature/Source of } \\
\text { Main Threats }\end{array}$} & $\begin{array}{c}\text { Likelihood of Severe Realization in } \\
\text { the Next Three Years }\end{array}$ & $\begin{array}{c}\text { Expected Impact on Financial } \\
\text { Stability if Threat is Realized }\end{array}$ \\
\hline $\begin{array}{l}\text { Prolonged weakness } \\
\text { in tourism sector }\end{array}$ & $\begin{array}{c}\text { Staff assessment: High } \\
\text { Recent political events have } \\
\text { discouraged tourism and the } \\
\text { sector is currently in a severe } \\
\text { slump. The recession in Europe } \\
\text { is expected to negatively affect } \\
\text { tourism in the short-term, } \\
\text { hampering the economic } \\
\text { recovery. }\end{array}$ & $\begin{array}{l}\text { Staff assessment: Medium } \\
\text { Banks have large exposures to } \\
\text { the tourism sector, and there are } \\
\text { questions about the } \\
\text { recoverability of collateral. The } \\
\text { weakness in the tourism sector } \\
\text { has yet to show up as an } \\
\text { increase in NPLs, but there are } \\
\text { concerns that the data are } \\
\text { distorted by regulatory } \\
\text { forbearance. }\end{array}$ \\
\hline
\end{tabular}


Table 4. Tunisia: Implementation of 2006 Recommendations

\begin{tabular}{|c|c|c|}
\hline Recommendations & Timeframe & Assessment \\
\hline \multicolumn{3}{|l|}{ A. Banking sector issues } \\
\hline $\begin{array}{l}\text { Ensure rigorous implementation of the authorities' target of } 70 \text { percent } \\
\text { provisioning for all NPLs, without regard for existing collateral. }\end{array}$ & MT & The 70 percent target was not met. \\
\hline $\begin{array}{l}\text { Reduce by } 2009 \text { the ratio of NPLs to total loans to no more than } \\
10 \text { percent of loans through a proactive policy of loan restructuring, } \\
\text { including partial write-offs, accompanied by safeguards against moral } \\
\text { hazard. }\end{array}$ & MT & NPLs stood at 13 percent in 2010. \\
\hline $\begin{array}{l}\text { Accelerate restructuring of bank loans to the tourism sector on the basis } \\
\text { of a realistic assessment of debt repayment capacity of the borrowers. }\end{array}$ & ST & $\begin{array}{l}\text { A few loans were restructured, but structural issues continued to } \\
\text { increase the number of problem loans in the tourism sector. }\end{array}$ \\
\hline Ensure that partial write-offs benefit from tax deductibility. & ST & Not implemented. \\
\hline Promote extrajudicial procedures for bank debt restructuring. & ST & $\begin{array}{l}\text { The regime remains unchanged. Debt recovery through courts is } \\
\text { still slow, while pre-bankruptcy rescue procedures are not often } \\
\text { used in practice. }\end{array}$ \\
\hline $\begin{array}{l}\text { Strengthen management of public commercial banks, ensuring full } \\
\text { independence of management, tighter risk management procedures, and } \\
\text { improved estimate of NPL recovery prospects. }\end{array}$ & ST & $\begin{array}{l}\text { Little progress has occurred. The governance structure of public } \\
\text { bank needs to be examined and strengthened. }\end{array}$ \\
\hline $\begin{array}{l}\text { Establish program contracts with management of public banks with } \\
\text { quantitative operational targets. }\end{array}$ & ST & Not implemented. \\
\hline $\begin{array}{l}\text { Stand ready to recapitalize public banks if operating income is not } \\
\text { sufficient to reach the } 70 \text { percent provisioning target for NPLs. }\end{array}$ & MT & $\begin{array}{l}\text { No measures are in place yet to recapitalize banks and } \\
\text { provisioning is not adequate as it is based on optimistic collateral } \\
\text { assessments. }\end{array}$ \\
\hline $\begin{array}{l}\text { Maintain prohibition of dividend distribution for banks that have } \\
\text { inadequate NPL provisioning. }\end{array}$ & ST & $\begin{array}{l}\text { Not implemented. No sanctions have been applied, including the } \\
\text { prohibition of dividend distribution. }\end{array}$ \\
\hline $\begin{array}{l}\text { Speed up privatization and mergers of former development banks that } \\
\text { have recently received universal banking licenses. }\end{array}$ & ST & $\begin{array}{l}\text { Initiatives have been taken, but noticeable progress still has to } \\
\text { come. }\end{array}$ \\
\hline $\begin{array}{l}\text { Improve information system for lending to SMEs and households by } \\
\text { promoting establishment of private credit bureaus. }\end{array}$ & ST & No credit bureau has been established. \\
\hline \multicolumn{3}{|l|}{ B. Prudential supervision and regulation } \\
\hline $\begin{array}{l}\text { Ensure implementation of new rules on management of credit risk, } \\
\text { envisaged by new circular on internal controls. }\end{array}$ & ST & $\begin{array}{l}\text { Not addressed. A circular on Internal Control has been issued, but } \\
\text { the CBT has not taken adequate action to enforce it. }\end{array}$ \\
\hline Assess the quality of banks' internal audit functions. & MT & $\begin{array}{l}\text { The CBT has not assessed the quality of banks' internal audit } \\
\text { functions and no on-site inspections have been carried out since } \\
2006 \text {. }\end{array}$ \\
\hline Establish prudential ratios on a consolidated basis. & ST & Supervision is still performed on a solo basis only. \\
\hline $\begin{array}{l}\text { Enter into information-sharing agreements with other Tunisian financial } \\
\text { supervisors and foreign supervisors. }\end{array}$ & ST & Cooperation remains weak. \\
\hline
\end{tabular}


Table 4. Tunisia: Implementation of 2006 Recommendations (continued)

\begin{tabular}{|c|c|c|}
\hline Recommendations & Timeframe & Assessment \\
\hline $\begin{array}{l}\text { Tighten regulations regarding equity investments, and strengthen } \\
\text { enforcement. }\end{array}$ & ST & Not implemented. Enforcement is minimal. \\
\hline $\begin{array}{l}\text { Revisit the disciplinary sanction regimes by vesting the power to impose } \\
\text { sanctions in the Banking Commission, as envisaged in the banking law, } \\
\text { rather than in the governor of the central bank, to promote transparency. }\end{array}$ & ST & Not implemented. \\
\hline \multicolumn{3}{|l|}{$\begin{array}{l}\text { C. Central bank policy, systemic liquidity management, } \\
\text { and foreign exchange markets }\end{array}$} \\
\hline $\begin{array}{l}\text { Disclose more clearly in the CBT publications the monetary framework in } \\
\text { terms of ultimate, intermediate, and operational objectives. }\end{array}$ & ST & $\begin{array}{l}\text { Noticeable efforts have been made to explain monetary policy } \\
\text { decisions in CBT publications. }\end{array}$ \\
\hline $\begin{array}{l}\text { Deepen interbank markets by allowing wider money market rates } \\
\text { fluctuations. }\end{array}$ & ST & $\begin{array}{l}\text { The CBT introduced an interest rate corridor in line with best } \\
\text { international practices. The interbank market did not deepen, } \\
\text { however, because of inconsistencies in the monetary and foreign } \\
\text { exchange framework. }\end{array}$ \\
\hline Publicize more widely the newly established bond yield curve. & ST & $\begin{array}{l}\text { Monetary policy transparency has improved slightly, but not } \\
\text { enough to establish a yield curve }\end{array}$ \\
\hline Repeal the current foreign exchange surrender requirement on banks. & ST & $\begin{array}{l}\text { The surrender requirement has not been repealed, despite the } \\
2008 \text { recommendation from the MOF in favor of a partial repeal } \\
\text { (20 percent). }\end{array}$ \\
\hline $\begin{array}{l}\text { Relax restrictions on forward foreign exchange cover for commercial } \\
\text { operators. }\end{array}$ & ST & $\begin{array}{l}\text { The forward regulation has not been revised to address this } \\
\text { recommendation. }\end{array}$ \\
\hline \multicolumn{3}{|l|}{ D. Corporate debt restructuring } \\
\hline Promote use of expert workout specialists in judicial reorganizations. & ST & Not implemented. \\
\hline $\begin{array}{l}\text { Ensure that judicial proceedings for companies restructuring are not } \\
\text { hampered by excessive delays. }\end{array}$ & ST & Not implemented. \\
\hline $\begin{array}{l}\text { Promote extra-judicial procedures, with preset rules for creditors and } \\
\text { debtors, to speed up agreements. }\end{array}$ & ST & Not implemented. \\
\hline $\begin{array}{l}\text { Review the preferred creditor status of tax authorities and social security } \\
\text { agency claims. }\end{array}$ & ST & Not implemented. \\
\hline \multicolumn{3}{|l|}{ E. Collateral registration and realization } \\
\hline $\begin{array}{l}\text { Speed up real estate titles registration, registration of changes in property, } \\
\text { and registration of mortgages. }\end{array}$ & ST & $\begin{array}{l}\text { Progress is under way. A } 2010 \text { law paved the way for electronic } \\
\text { exchanges between the land registrars and the "Tribunal } \\
\text { Immobilier." These specialized courts, in charge of the integration } \\
\text { of unregistered properties and updating of titles of commonly } \\
\text { owned or transferred properties, lack operational resources. }\end{array}$ \\
\hline
\end{tabular}


6. A key component of the 2006 FSAP was a set of recommendations aimed at addressing banks' nonperforming loans (NPLs). These included stronger risk management to better identify creditworthy borrowers, the elimination of legal and tax obstacles to partial writeoffs, and the facilitation of loan restructuring when appropriate. The FSAP stressed the importance of monitoring banks' implementation of these new rules, restructuring practices, and compliance with provisioning requirements.

\section{Financial Stability Analysis}

\section{This assessment has taken a much more critical view of the Tunisian system than} the 2006 FSAP for several reasons. First, the authorities' own commitment to reform of the financial sector meant that the team had greater access to information and was much better able to identify weaknesses than otherwise. Second, the standards against which banking supervision practices are assessed have been tightened considerably, both as part of the revision to the standard in 2006 and in response to the lessons learned as a result of the ongoing global financial crisis. Third, the quality of banking supervision capacity at the CBT deteriorated significantly during the 2006-2011 period. Finally, these weaknesses were compounded by the 2011 turmoil, and some measures taken by the new authorities at that time to support the economy may have allowed additional vulnerabilities to accumulate.

\section{A. Financial System Structure}

\section{In 2011, the Tunisian financial sector was small and dominated by banks, with} assets equal to about 115 percent of GDP. This figure is somewhat lower than its regional peers such as Egypt, Jordan, Lebanon, and Morocco. As of April 2012, there were 21 onshore banks, including three large state-owned banks with 37 percent of banking sector assets; three large private domestic banks with 28 percent of total assets; and six foreign-owned private banks with a 28 percent share. Of these, four large foreign banks (from France, Jordan, and Morocco), three are former state-owned banks, only one of which appears to have completed its restructuring, There are five small development banks, established partially with funds from the Gulf States, and enjoying universal banking licenses.

9. More than half of total bank credit is provided to the industrial, trade, and tourism sectors. A large part of the remaining credit appears to be provided to the public sector, although data were not available to confirm this. The composition of deposits did not change significantly in recent years, with households and private companies accounting for about half and one-quarter of total deposits, respectively.

10. The nonbank financial sector is relatively small. It accounts for about 20 percent of all financial system assets in 2011. Tunisia has a small insurance sector, with 19 companies primarily focused on nonlife activities ( 85 percent of premiums) and annual premiums to GDP of about 2 percent. The equity and fixed-income markets are still small, with a market capitalization equal to 24 percent of GDP, lower than in regional peer countries such as Jordan (112 percent) 
and Morocco ( 76 percent). Private equity remains small and the leasing sector, with nine institutions, accounted for 151/2 percent of private gross fixed capital formation in 2010.

\section{B. Banking System Vulnerabilities}

11. The reported data suggests that banks' financial positions have not deteriorated, despite recent political turmoil and a weak domestic economy (Table 6). At end-2011, the official level of NPLs was 13 percent, down from over 19 percent in 2006. Regulatory capital remained almost unchanged at 11.5 percent of risk-weighted assets, and bank profitability remained relatively high (the average return on equity (ROE) was 7.9 percent).

\section{Banking sector vulnerabilities are likely to be much higher than implied by officially} reported balance sheet data for several reasons.

- In mid-2011, the CBT issued a circular allowing banks to reschedule loans due from companies hurt by the political turmoil of 2011. Reclassifying these rescheduled loans as nonperforming would add about 5 percent to the overall NPL ratio. ${ }^{1}$

- Loans to public enterprises are never classified because of a (presumed) government guarantee.

- Weak reporting practices and deficiencies in the supervisory framework undermine the quality of reported figures, which are not compiled in line with international best practices, contain significant gaps, and in several cases are not subject to banks' internal audits.

\section{The mission strongly urged the authorities to address the weakness of supervisory} data. In particular, it would be important to produce reliable financial sector indicators (FSIs) in order to understand the current state of the banking sector. As a first step, a uniform database and standardized template should be developed to allow more frequent, detailed, and consistent monitoring of bank performance.

\footnotetext{
${ }^{1}$ The most recent data, as of end-April 2012, indicate that the volume of loans rescheduled under the circular has risen sharply to about TD 5 billion or 7.7 percent of GDP.
} 
Table 5. Tunisia: Financial Soundness Indicators, 2006-2011

(In percent)

\begin{tabular}{lrrrrrr}
\hline & \multicolumn{1}{c}{2006} & \multicolumn{1}{c}{2007} & 2008 & 2009 & 2010 & 2011 \\
\hline Capital adequacy ratio, of which: & 11.8 & 11.6 & 11.7 & 12.2 & 11.6 & 11.5 \\
$\quad$ Private & 12.1 & 9.7 & 11.0 & 11.6 & 11.7 & 11.7 \\
$\quad$ Public & 9.3 & 9.9 & 9.6 & 10.5 & 10.0 & 9.8 \\
Gross nonperforming loans & 19.3 & 17.6 & 15.5 & 13.2 & 13.0 & 13.0 \\
$\quad$ percent of gross assets) of & & & & & & \\
$\quad$ which: & 19.0 & 18.1 & 15.3 & 12.5 & 10.4 & 10.2 \\
$\quad$ Private commercial banks & 19.7 & 17.3 & 15.9 & 14.1 & 16.3 & 16.4 \\
$\quad$ Public commercial banks & 49.0 & 53.2 & 56.8 & 58.3 & 58.5 & 59.6 \\
Provisions & & & & & & \\
$\quad$ (percent of nonperforming loans) & & & & & & \\
$\quad$ of which) & 48.4 & 52.0 & 55.0 & 59.2 & 67.7 & 67.9 \\
$\quad$ Private & 50.2 & 55.0 & 58.1 & 57.0 & 50.1 & 49.2 \\
$\quad$ Public & 34.2 & 37.5 & 37.1 & 37.2 & 34.7 & 30.5 \\
Liquid assets to total assets & 120.8 & 121.9 & 124.0 & 119.1 & 104.1 & 89.4 \\
Liquid assets to liquid liabilities & 99.1 & 104.8 & 104.5 & 106.9 & 100.7 & 92.9 \\
Deposits to loans & 1.0 & 1.0 & 1.4 & 1.5 & 1.3 & 1.9 \\
Net open position in foreign & & & & & & \\
exchange & & & & & & \\
Return on assets & 7.0 & 10.1 & 11.2 & 11.7 & 10.2 & 7.9 \\
Return on equity & & & & &
\end{tabular}

Source: Central Bank of Tunisia.

14. The value of banks' collateral may be significantly overestimated. Total reported collateral values represent about 50 percent of the value of NPLs, even though a large share of this collateral is more than five years old. Experience in other countries with similar ratios of collateral value to NPLs suggests much lower recovery rates, and discussions with banks suggest that recovery rates could be well below 50 percent, and for some loans below 10 percent. $^{2}$ The mission looked in detail at one large troubled public bank and concluded that its loan portfolios were significantly overvalued and that a proper revaluation of collateral could leave the bank insolvent.

\footnotetext{
${ }^{2}$ Recoveries as a share of loan value in the United States (1980-1994); Slovakia, 2001; Mexico, 2007 and 2008; and Indonesia, 2001-2005, ranged from 3 percent to 41 percent (Sources: FDIC, ADB paper on AMCs, and staff estimates).
} 


\section{Inflated collateral valuation means that provisioning for bad loans is likely} inadequate, since provisions are calculated on a net-of-collateral basis. ${ }^{3}$ The team stressed the importance of applying international standards to loan classification, provisioning, and valuation of collateral, and cautioned that weaknesses in these areas seriously compromise the ability of the CBT to estimate and address the vulnerability of the banking sector.

16. The tourism sector presents a particularly serious risk for banks in Tunisia. Over the last 15 years, multiple structural issues have undermined the financial soundness of the tourism sector, and, more recently, political instability and security concerns have pushed the sector in a severe recession with tourism revenues falling by about 40 percent. Out of the 850 hotels, it is reported that one-third is likely to be in severe financial distress during 2011.

\section{Banks' shortage of liquidity has been mitigated so far by central bank liquidity} support. Banks are not reliant on external funding, and capital controls limit possibilities for deposit flight. However, depositors can shift their deposits into cash relatively easily; recently deposit growth slowed while currency in circulation increased. Nonetheless, credit growth remained strong, since banks have been provided ample liquidity by the CBT at interest rates that are negative in real terms. ${ }^{4}$

18. Banks are exposed to interest rate risk. There is a structural maturity mismatch in bank portfolios because a large share of banks' assets have medium- to long-term maturities and are primarily funded by short-term liabilities (essentially, but not only, composed of customer deposits). Capital controls limit exposures to international rates, and domestic interest rates have remained low so far. However, this situation could change rapidly, as was illustrated when term deposit rates increased sharply in 2011.

19. Banks do not appear to be exposed to significant direct exchange rate risk. Banks reported that they had low exposures in foreign currency, averaging less than 5 percent of total lending, with small amounts of loans to borrowers in export industries. Foreign exchange regulation forbids banks from investing abroad.

\section{Banking Stress Tests}

20. Stress tests indicate that the banking sector may face large recapitalization needs even to meet the current 8 percent regulatory minimum. These stemmed from an underestimation of existing shortfalls, as well as from the likelihood of a worsening of loan quality. The team, therefore, recommended that banks should immediately begin setting aside additional capital. Large recapitalizations of public banks represent a potential fiscal liability, which may affect macroeconomic stability.

\footnotetext{
${ }^{3}$ In extreme cases where banks provision fully without netting out collateral, the average CAR falls to 5.4 percent.

${ }^{4}$ The CBT increased its refinancing to a total of TD 4.8 billion on average in May 2012 or about 7.3 percent GDP. Since June 2011, the CBT policy rate has been set at 3.5 percent. For more information, see the section on liquidity.
} 
21. In particular, the mission conducted solvency and liquidity stress tests on the banking system. The solvency tests simulated the impact of adverse scenarios on the solvency of banking system for the period 2012 to 2014. The analysis used a top-down approach based on a bank-by-bank prudential balance sheets data and applying Basel I capital metrics to risk weights. The liquidity tests assessed potential vulnerabilities to short-term liquidity shocks. All stress tests were undertaken in close consultation with the authorities. The tests had a wide institutional coverage - including 17 out of 21 Tunisian banks with 97 percent of the assets of the banking system - but the quality of the analysis was constrained by significant shortcomings in supervisory data.

22. The solvency tests simulated bank performance under a baseline scenario and an adverse scenario for the period 2012 to 2014 (Figure 1). The baseline scenario included a moderate pick-up in growth in 2012, followed by strong medium-term performance. ${ }^{5}$ An adverse scenario simulated a further negative growth shock in 2012, followed by a gradual but lower medium-term recovery to a moderate growth level. Additional adjustments included the impact of a downward revision in the value of collateral assigned to NPLs and provisioning for rescheduled loans (Table 7).

23. Under the adverse scenario, additional capital equivalent to over 5 percent of GDP would be required to bring banks to the 8 percent minimum. Even under the baseline scenario, there is a projected recapitalization need of almost 3 percent of GDP within two years. ${ }^{6}$ However, in the averse scenario, two out of three public banks and some foreign-owned banks, representing almost two-fifths of the banking sector assets become insolvent within two years. The team also considered the implications of the fact that public banks reported that they rescheduled loans at significantly lower rates than did private banks. Since there was no clear explanation for this difference, the team considered the impact of increasing public banks' rescheduling rates (and associated losses) to the same level as those of private banks, and found that this would increase the recapitalization needs of the banking sector to 7 percent of GDP in the adverse scenario.

24. Concentration risks are large, and banks are highly vulnerable to default by their largest borrower. Five banks become insolvent in the first year and two more in the second year under the adverse macro scenario if the largest borrower at each bank defaults. The banks most affected are those whose portfolios include loans to large public sector entities, though these entities have an implicit state guarantee.

\footnotetext{
${ }^{5}$ The macro scenarios underlying the stress tests, which were prepared in January, differ from the most recent staff projections and alternative scenario, which were updated during the recent Article IV mission.

${ }^{6}$ The CAR ratios at end-2011 differ substantially from those eventually reported by the authorities for end-2011 because the authorities did not make adjustments for rescheduling.
} 
Table 6. Tunisia: Solvency Test-Assumptions

\begin{tabular}{|c|c|c|c|c|c|c|c|c|}
\hline \multirow{2}{*}{\begin{tabular}{|l} 
Domain \\
Scenarios
\end{tabular}} & \multirow{2}{*}{$\begin{array}{l}\text { Element } \\
\text { (i) Baseline; (ii) Double Dip }\end{array}$} & \multicolumn{7}{|c|}{ Specific Rules/Assumptions } \\
\hline & & \multicolumn{7}{|l|}{ Macroecono } \\
\hline & & & 2011 & 2012 & 2013 & 2014 & 2015 & 2016 \\
\hline & & \multicolumn{7}{|c|}{ Real GDP Growth (\%) } \\
\hline & & Actual baseline & -0.8 & 2.2 & 3.5 & 4.8 & 6.5 & 6.7 \\
\hline & & Adverse & -0.8 & -1.6 & -0.7 & 0.3 & 1.2 & 2.1 \\
\hline & & \multicolumn{7}{|c|}{ - $\quad$ Aim to ensure broad consistency in growth rates with other European FSAPs. } \\
\hline $\begin{array}{l}\text { Factors } \\
\text { assessed }\end{array}$ & $\begin{array}{l}\text { For the two scenarios, these } \\
\text { factors are assessed alone or } \\
\text { combined }\end{array}$ & \multicolumn{7}{|c|}{$\begin{array}{l}\text { - } 2011 \text { leveling: Adjust provisioning by assuming that the value of the collateral is } \\
\text { divided by two; Adjust stock of NPL by incorporating half of rescheduled loans. } \\
\text { - Default rate: based on bank-level data. The } 2011 \text { total NPL flow is estimated at TD } \\
\text { 2.6 Billion in both scenarios. For the following years, a "rule of thumb" based on } \\
\text { empirical results in a range of countries links credit losses variations to } \\
\text { macroeconomic conditions. } \\
\text { - Concentration Risk: the default of the largest individual counterpart is simulated. }\end{array}$} \\
\hline $\begin{array}{l}\text { General } \\
\text { assumptions }\end{array}$ & & \multicolumn{7}{|c|}{$\begin{array}{l}\text { - Credit growth: growth of total credit exposure by } 10 \text { percent every year. } \\
\text { - RWA: calculated under Basel I. The model allows for a decrease of RWAs for } \\
\text { defaulted credit exposure. } \\
\text { - Profit: no change. } \\
\text { - Income retention rate: the level is fixed at } 100 \text { percent. This assumes conservative } \\
\text { behavior by banks. }\end{array}$} \\
\hline Outcome & Template and assumptions & \multicolumn{7}{|c|}{$\begin{array}{ll}\text { - } & \text { Metrics: total capital ratios. } \\
\text { - } & \text { Results: per bank. }\end{array}$} \\
\hline
\end{tabular}

Source: Fund Staff estimates. 


\section{Table 7. Tunisia: Liquidity Test-Assumptions}

\begin{tabular}{|c|c|c|}
\hline Type of tests & $\begin{array}{l}\text { Assess the sensitivity of banks } \\
\text { against outflow of funding through } \\
\text { two independent tests }\end{array}$ & $\begin{array}{l}\text { (i) Simulation of gradual outflow of customer deposits, taking into account of "fire sales" } \\
\text { of liquid assets by banks. } \\
\text { (ii) Simulation of sudden outflow of CBT funding corresponding to non-renewal of short- } \\
\text { term (7days) refinancing. }\end{array}$ \\
\hline Assumptions & $\begin{array}{l}\text { Outflow of liabilities; liquidity of } \\
\text { assets to be used for fire sales of } \\
\text { assets }\end{array}$ & $\begin{array}{l}\text { Liquidity need is not taking into account possible "flight to safety" or other flows among } \\
\text { banks. } \\
\text { (i) Assumptions for outflow of customer deposits. } \\
\text { - } 10 \text { percent outflow of customer deposits during each period (both portions of the } \\
\text { then remaining deposits). } \\
\text { - } \quad \text { Fire sales of liquid assets (haircut in percent) : cash (0), Government bond and T- } \\
\text { bills holding (0), half of them already encumbered. } \\
\text { - CBT accepts long-terms loan as collateral ( } 90 \text { percent), assuming } 50 \text { percent of it is } \\
\text { already encumbered. } \\
\text { (ii) Assumption for outflow of CBT funding : } \\
\text { - } 30 \text { percent outflow of CBT funding (corresponding to half of the December } 2011 \\
\text { percentage of } 7 \text { days refinancing), then } 50 \text { percent outflows (half of the } 7 \text { days } \\
\text { refinancing as of June } 2011 \text { ). } \\
\text { - Fire sales of liquid assets (haircut in percent) : cash (0). }\end{array}$ \\
\hline Outcome & Template & - $\quad$ Outcome bank by bank: number of illiquid banks in each (i) and (ii) tests. \\
\hline
\end{tabular}

Source: Fund Staff estimates. 
25. Liquidity stress tests show that banks are dependent on CBT refinancing and are vulnerable to large withdrawals of customer term deposits. Some banks have insufficient liquidity to manage a sharp reduction in the CBT seven-day refinancing program, meaning that the CBT cannot quickly reverse its policy of providing liquidity support to banks while encouraging them to lend to support the economy. A 50 percent reduction in seven-day funding by the CBT would cause four banks to become illiquid. Banks are able to manage deposit withdrawals of up to 10 percent without difficulty, but four banks become illiquid if term deposit withdrawals exceed 10 percent (Table 9).

\section{BANKING SUPERVISION AND FInANCIAL StABILITy ARRANGEMENTS}

\section{A. Banking Regulation and Supervision}

26. Starting from an extremely weak position at end-2010, the CBT has made commendable strides in strengthening banking supervision. After years of neglect, in 2011, the new CBT management indicated its intention to refocus the CBT on its core mission and a medium-term plan to build effective banking supervision was initiated in February 2012. The plan included a new organization, and reassignment and recruitment of staff. The CBT also adopted a new corporate governance regime for commercial banks to increase the role and independence of commercial bank Boards.

27. Nonetheless, bank supervision and regulation is still extremely weak. The team reviewed banking regulation and supervision practices using Basel Core Principles for Effective Banking Supervision (BCP) as a benchmark, and the outcomes are summarized in this section. The Banking Supervision Department (BSD) comprised 37 staff, about half the 2006 level, which was insufficient even then. The 2011 revolution exposed major governance issues under the former regime (i.e., influence of relatives of the former president over the banking system), which may explain the observed deterioration in financial supervision.

28. Strengthening supervisory resources is a priority. The team called for the development of a well-trained staff that can effectively apply prudential supervision, and for the strengthening of on-site and off-site procedures and tools. This would require the BSD to have sufficient resources and to be equipped with an adequate and modern IT infrastructure. The team cautioned that the observed weaknesses could not be solved by internal rotation and new hiring of graduates, and encouraged the CBT to hire staff with market experience and make use of international consultancy firms.

29. Reporting and management of financial sector data need to be significantly improved. Banks should be required to report a full set of financial sector and loan-portfolio indicators, including on capital, liquidity, foreign exchange, loan quality, and rescheduling. The CBT needs to improve its data-management capacity and coordinate its financial reporting, so that the statistics it provides are complete, consistent, and accessible in electronic format. 
30. Full on-site inspections have not been held since 2006, and should be conducted for all banks. These inspections should start by covering the largest banks and focus on credit risk, large exposures, and related-party lending, liquidity, risks born by subsidiaries, internal control, and information systems. The CBT needs rapidly to have a clear, in-depth, and reliable understanding of each bank's situation, starting with the largest ones, especially given the extremely challenging economic conditions they face. Many banks have very poor internal controls and, in some cases, even external auditing has been poor.

31. Minimum capital adequacy requirements are too low considering the risks faced by the Tunisian banking system. A first step should be to increase the minimum CAR from 8 percent to 10 percent by 2014 . The CAR should be further increased to 12 percent by 2016 . The CBT should also impose higher solvency requirements to individual banks that are found to be taking on greater risk. Increasing the minimum CAR to 10 percent by 2014 would require banks to increase their capital by the equivalent of approximately 1.3 percent of GDP.

32. The CBT needs to have effective independence and accountability. Criteria for hiring and dismissal of the governor and board members need to be clear and transparent. Accountability mechanisms should include transparency on how missions are fulfilled and decisions taken. There should be no restrictions on the CBT's capacity to intervene in public banks as opposed to private banks; the same rules and regulations should apply to stateowned banks as to private banks. Clear conflict-of-interest policies should be established for current CBT staff, and for staff who leave for commercial banks and other financial institutions.

33. The CBT needs to strengthen its enforcement regime. Other than few minor penalties, no sanction has ever been imposed on a bank or its senior management, even though several banks are presently in breach of key regulatory and prudential requirements. This lack of action undermines the central bank's credibility and effectiveness. The CBT should take action against all banks that fail to meet prudential and legal requirements. It could usefully consider introducing a more formalized prompt corrective action (PCA) framework that would establish and require graduated interventions when a bank breaches key prudential triggers.

\section{B. Liquidity Arrangements}

\section{Tunisia's liquidity management instruments are broadly consistent with} international practices. It relies on an unremunerated reserve requirement with monthly averaging, open market operations, and standing lending and deposit facilities. The CBT liquidity forecasting is reasonably accurate. The CBT uses the relevant instruments required for efficient liquidity management, including an unremunerated reserve requirement based on monthly averaging, open market operations, and standing lending and deposit facilities.

\section{The minimum liquidity ratio and the reserve requirement should be de-linked.}

Currently, banks are required to maintain a higher level of reserves if they do not comply 
with the liquidity ratio. However, when systemic liquidity declines for the entire banking sector, this rule results in an increase in the reserve requirement that exacerbates the liquidity shortage.

36. Structural liquidity management should be significantly strengthened. As a first step, the liquidity drain from the banking system related to foreign exchange intervention should be stopped. In this regard, the envisaged reform of the exchange rate framework would allow a more flexible exchange rate with better management of CBT foreign exchange interventions. As a second step, to restore structural liquidity, the CBT should rely on outright purchases of government securities. This approach could be used to reduce banks' refinancing needs to a level consistent with a well functioning interbank market, which activity has been minimal due to systematic shortages of liquidity. Such actions would not only have positive macroeconomic effects, but also ultimately strengthen the banking system. Furthermore, banks should not have access to central bank loans to finance debt restructuring, but should instead rely on fiscal resources.

37. The current liquidity policy exposes the CBT to serious credit risk. The low CBT policy rate has promoted excessive lending and risk taking by banks. The pool of collateral eligible for CBT refinancing is relatively large, including treasury bonds and banks' loans to their clients. The CBT should accept this collateral, but at the current market value and associated credit risk. The CBT should provision part of its 2011 profit to cover these exposures. Meanwhile, the CBT should develop an exit strategy to unwind its liquidity support to banks by gradually increasing the cost of refinancing.

\section{Coordination between the prudential supervision and monetary policy} departments should be strengthened. The BSD should flag banks' solvency and portfolio performance problems more forcefully during CBT refinancing committee deliberations. The CBT should continue to meet banks' liquidity needs, , and it should introduce a lender of last resort facility to deal that have banks with insufficient eligible collateral outside of the CBT main refinancing operations.

\section{Crisis Management and Bank Resolution}

\section{The CBT and the Ministry of Finance (MOF) have no framework that defines}

their roles and responsibilities in a financial crisis. Furthermore, neither the MOF nor any other competent government agency has funding mechanisms in place to address intervention of a systemic bank, nor are there provisions allowing the advancement of funds for depositor pay-outs in the event of a bank failure

40. Steps should be taken to put in place an effective crisis management framework. A Memorandum of Understanding (MOU) should define the roles and responsibilities of the main institutions and authorities in the event of a systemic crisis, and the legal framework needs to be reviewed to ensure that these officials have sufficient legal authority to undertake 
actions envisaged in the MOU. The MOF should develop an explicit mechanism for funding the rescue of a systemic bank.

\section{Deposit insurance scheme (DIS)}

41. The authorities should consider the introduction of a credible, explicit, and limited DIS once the necessary preconditions are in place. The Law on Credit Institutions provides for an unfunded, indeterminate deposit guarantee, but this is insufficient to prevent contagion and poses fiscal risks. The law states that the CBT shall determine any deposit insurance at the time of bank failure, including the level of reimbursement, any reimbursement conditions, and the timeline for reimbursement. This poses risks of moral hazard, while still leaving the system vulnerable to deposit flight in the event of a shock to confidence. Strengthening banking supervision is an important precondition to the introduction of DIS.

\section{Bank resolution}

42. The CBT has the power to mandate actions by a troubled bank, but this procedure falls short. The CBT may request that the MOF revoke a bank license. Once a license has been revoked, the MOF appoints a liquidator who reports to the CBT. However, in the absence of a reliable DIS, payment of depositor claims, especially those of small depositors, would be delayed until funds could be secured through judicial or nonjudicial collection or sale. The lack of any basis for ensuring prompt access to funds means that the system could be vulnerable to rapid deposit flight.

\section{A special resolution regime should be introduced and bank-restructuring} processes should be streamlined. The CBT must be able to revoke a bank license, trigger a nonjudicial procedure for resolving a troubled bank, manage the prompt payout of small depositors preferably from a DIS, and effectively liquidate and recover all remaining assets for other depositors and creditors generally.

\section{Liquidity support}

\section{A revised LOLR framework should give the CBT explicit power to advance} funds, secured by acceptable collateral, to solvent but illiquid banks. Such support should be linked to corrective actions. The Central Bank Act currently does not distinguish between types of CBT lending, whether related to monetary policy, liquidity functions, or the LOLR function. It explicitly grants authority only to lend to meet credit distribution or monetary goals, and the CBT uses this provision as a basis for its lending to banks. The CBT should explicitly segregate its power into two parts - the first dealing with monetary functions and the second with an LOLR facility. 


\section{IMPROVING FINANCIAL INTERMEDIATION EFFICIENCY}

\section{A. Industry Structure and Bank Competition}

45. Banking reforms undertaken since the early 2000 s did not lead to the anticipated financial deepening. Reforms consisted of making all banks universal, resolving small, poorly performing state-owned banks by selling them to foreign banks, and injecting resources into the three largest state-owned banks. Financial deepening has been limited, despite annual economic growth close to 5 percent over the past decade; progress in product innovation and quality service has generally been low, even if the situation varies across banks.

46. The regulatory framework has not provided a level playing field across banks. Although progress has been observed recently, some banks have been allowed to carry out their activities without meeting risk-management standards and key regulatory requirements. The existence of weak or nonviable institutions able to initiate new operations is highly detrimental to competition, as it puts pressure on prices and lowers risk-management standards.

47. Contestability in the Tunisian banking system remains limited. Foreign entry was allowed only on condition that new banks buy distressed institutions at prices that represent significant barriers to entry. Green-field banks have generally not been allowed.

48. Heavy state involvement in the financial sector distorts competition. The state plays a critical role directly through state-owned banks and, indirectly, through state-owned enterprises, which are important clients of all commercial banks. Poorly performing public banks are provided with recapitalization by the state, when needed, without changing their governance structure.

\section{B. State-Owned Banks' Restructuring}

49. The state-owned banks have been subject to conflicting mandates and have performed poorly. The Board and senior management are expected to serve the shareholders, including minority investors, but direct state intervention in the strategic direction and management of these banks, as mandated by law, has served other objectives, including supporting state-owned enterprises and entities. Laws making it more difficult for state-owned commercial banks to build up an effective governance structure and oversight mechanisms need to be revised, and the governance of state-owned banks need to be strengthened, with a focus on the independence of their Boards and senior management. More generally, the benefits and rationale for extensive state ownership of the banking sector are unclear, and the authorities should develop a strategy to limit state ownership of banks to cases of clear public policy need. 
50. The largest state-owned bank has large unrealized loan losses and needs to be restructured. Recapitalization of this bank would not be sufficient to address its underlying weaknesses, and liquidation would be inefficient, as piecemeal sale of bank assets does not preserve franchise value. Instead, the team suggests that the assets of this bank be separated into a "good bank" and a "bad bank," and the current management should be replaced. The bad assets should be marked-to-market and placed in a special recovery company. Any balance sheet shortfall should be covered by state recapitalization, the cost of which should be transparently identified in the fiscal budget.

\section{Small- and Medium-Sized Enterprise Finance}

51. State initiatives to support SME finance need to be reassessed before they are scaled up. Multiple initiatives to provide direct support to SMEs have resulted in a complex, redundant, and difficult-to assess-framework. A partial credit guarantee scheme and a stateowned SME bank were set up in the mid-2000s. The impact of these initiatives has been limited and the quality of the bank's portfolio raises concerns. NPLs have been growing at a rapid pace (19 percent in 2011), and the associated risks have not been properly identified and provisioned for.

52. The authorities need to address the information gap on SME finance. It has so far proved difficult to quantify and understand SME finance in Tunisia, and to assess the effectiveness of state intervention. The mission recommends assigning the CBT with responsibility to collect and publish detailed information on SME finance.

\section{Housing Finance}

53. Developers' loans are rapidly deteriorating and require close monitoring. In 2011, NPLs stood at a 13.1 percent of this portfolio. More worrying, the stock of NPLs increased by 55 percent, with the sharpest deterioration observed in the substandard categories (classes 2 and 3), which are typically less provisioned. The CBT should continue monitoring such risks on an ongoing basis, prepare guidance on the origination, rescheduling, and oversight of such risks, and ensure that banks recognize risks at an early stage and constitute adequate specific and general provisions (including on rescheduled loans).

\section{The authorities should require banks to strengthen their asset-liability}

management. Mortgage loans need to have long maturities to be affordable, but banks have few long-term resources. To address this problem, the CBT required banks to match all loans with a duration of over 10 years with long-term resources and to provide all loans with a duration of over 15 years at fixed rates. As a result, many banks simply reduced the maturities of their loans to avoid these constraints. Such regulations need to be better targeted with more granular thresholds. 


\section{E. Capital Market Development}

55. Capital markets do not play a major role in mobilizing savings and financing the real economy. Funds raised in the capital markets represent only 2 percent of GDP compared to private sector credit of 69 percent of GDP in 2011. The sovereign bond market meets minimum size requirements for inclusion in global indexes, but is underdeveloped and illiquid. The equity and corporate bonds primary markets are small, the secondary markets lack liquidity, and the companies listed do not reflect the structure of the Tunisian economy.

56. There are significant opportunities to increase the supply of fixed-income and equity products, and to promote long-term institutional investment. Key constraints include the dominant role of bank financing and the small size of most Tunisian firms, obstacles that some countries, including in the region, have overcome. The assets confiscated from the former president and his relatives, as well as other state-owned assets, could be offered to the public to provide investment opportunities. The lack of long-term institutional investors is a major constraint. A reform of the pension systems, which are financially strained, could help to build long-term investment demand in Tunisia. The short-term room for growth of foreign investor participation in both equity and fixed-income markets is uncertain.

\section{The dominance of banks in the financial system constrains capital market} development. Banks are not allowed to engage in brokerage activities but do so through subsidiaries, which have limited independence and a risk that their operations are not at arm's length. Intermediaries manage mutual funds, which are distributed to the banks' clients. A more independent CMA needs to step up its surveillance and strictly enforce its regulations in order to address these weaknesses.

\section{F. Access to Finance}

58. Access to finance remains limited. This is a major constraint in several regions and for some categories of workers. A microfinance law passed in October 2011 constitutes a major step forward. Regulations should be finalized and the supervision unit created, so that the law can be swiftly implemented. Additional reforms would be necessary, including broadening microfinance activities and transferring supervision to the banking supervision authority.

59. Improvements in bank intermediation and modernization of infrastructures are essential. The central bank operates a credit registry and other database, including on balance sheets. They could provide improved information and tools to assess SMEs' creditworthiness (e.g., more reliable and comprehensive data, and SME rating). The opportunity to allow credit bureaus could also be revisited considering their potential to better respond to the needs of credit institutions. 
60. The Post Office could usefully explore partnerships with other financial institutions to extend its product range. It has five million customers, a wide branch network, a performing information system, and offers cheap products primarily related to savings and payment.

\section{Anti-Money LAUndering ANd Combating THE FinAnCing OF TERRORISM (AML/CFT)}

61. The Tunisian AML/CFT regime was last assessed in 2006 by the World Bank.? Tunisia appears to have taken steps to strengthen its AML/CFT law, in line with the key recommendations of the assessment. Political changes in Tunisia and related efforts to trace and identify stolen assets have highlighted significant challenges in the implementation of the existing AML/CFT framework. In line with the authorities' intention to strengthen their AML /CFT framework further and given that the existing assessment is more than five years old, it has been agreed that a new assessment of the AML/CFT regime would be conducted toward the end of 2012.

\footnotetext{
${ }^{7}$ The assessment report was approved in April 2007 by the Middle East and North Africa Financial Action Task Force (MENAFATF), the FATF-style regional body.
} 
Figure 1. Tunisia: Solvency Tests and Macroeconomic Scenarios (In percent, unless indicated otherwise)

Tunisia : GDP Growth Scenarios

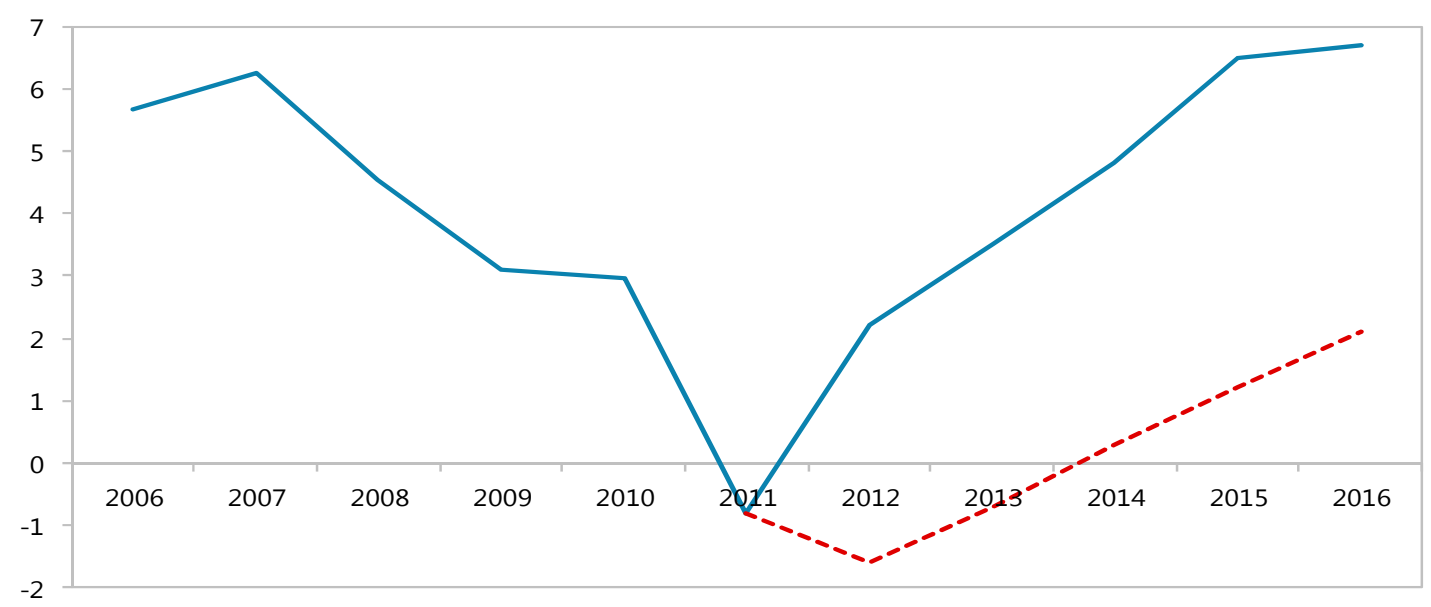

Tunisia : Default Rate

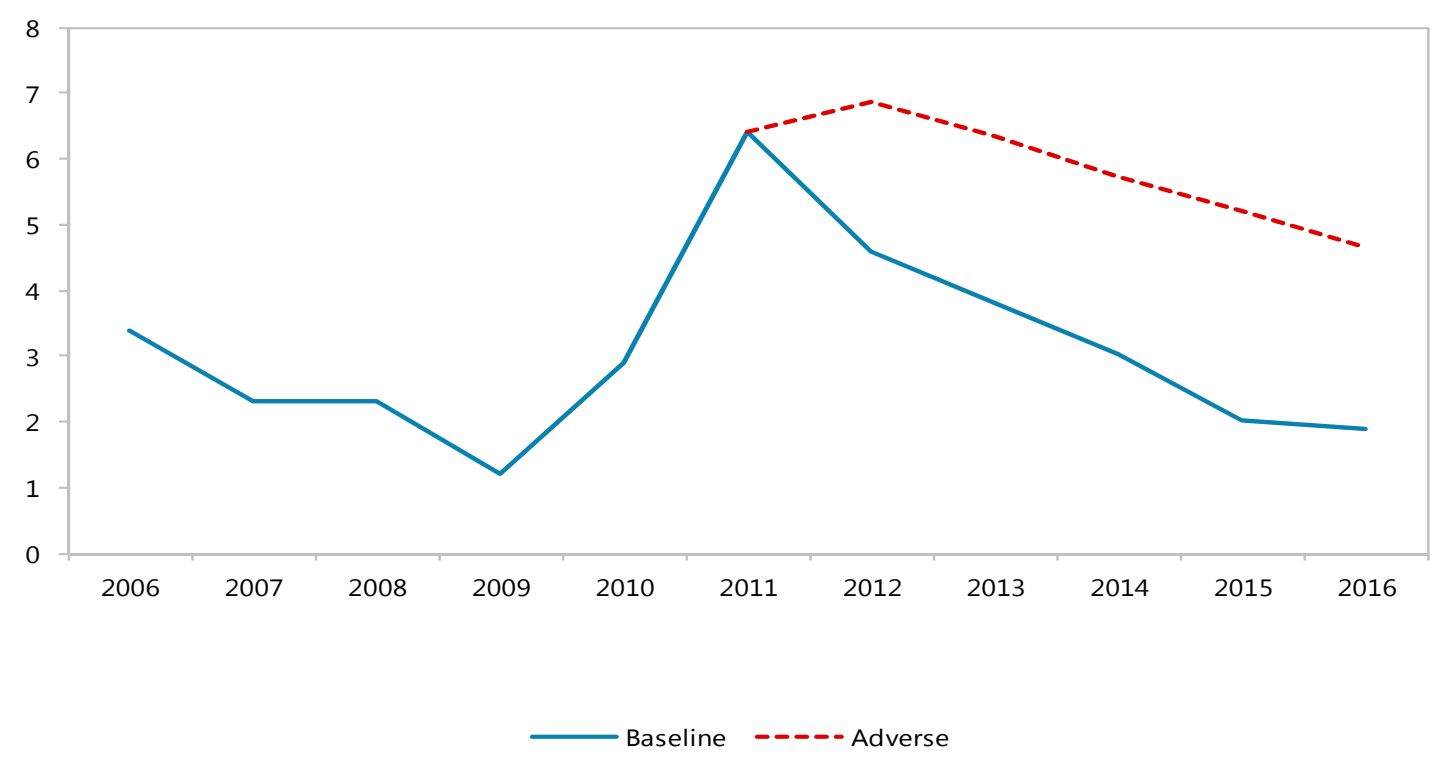

Source: Fund Staff estimates 
Figure 2. Tunisia: FSIs Peer Countries Analysis, 2005-2010

(In percent, unless indicated otherwise)

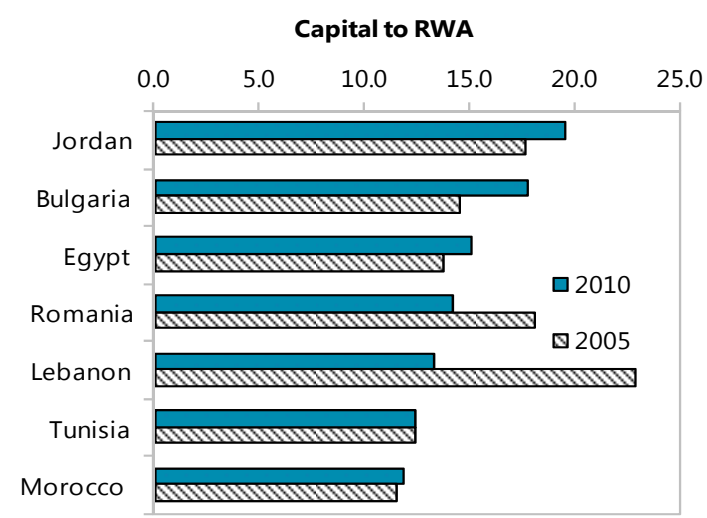

NPL Ratio
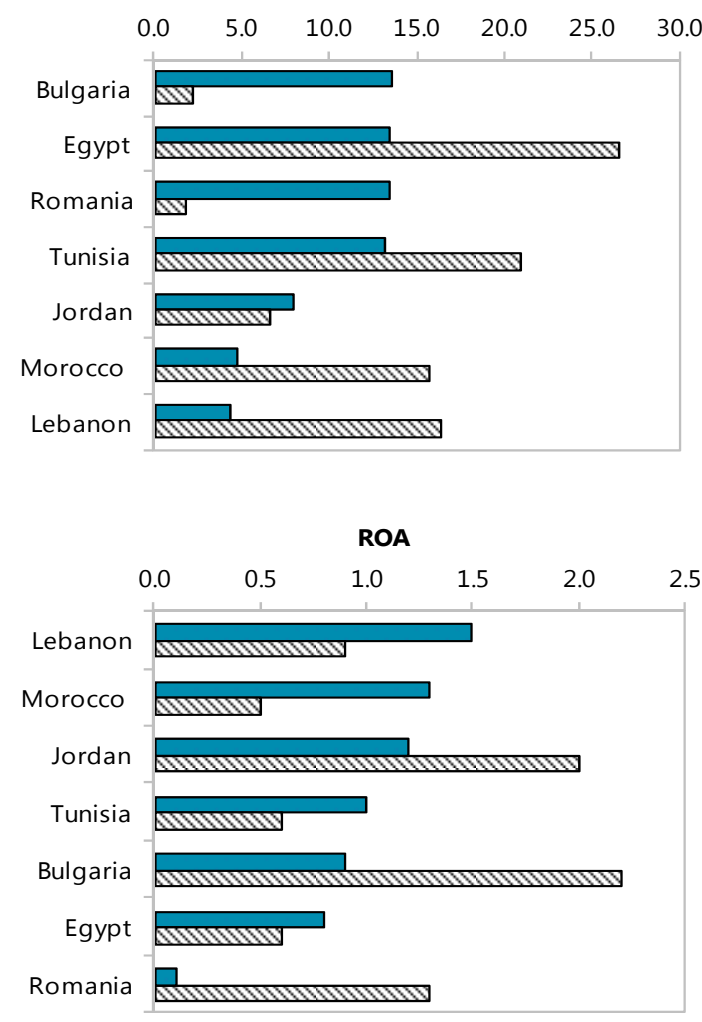

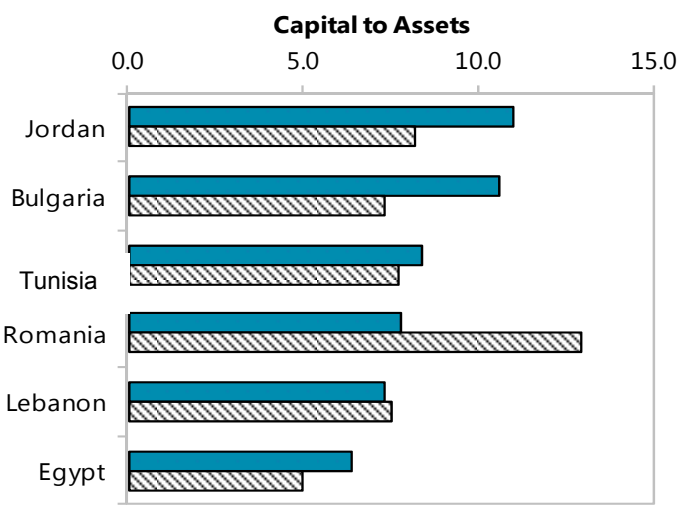

\section{Loan Loss Provisions to NPLs}

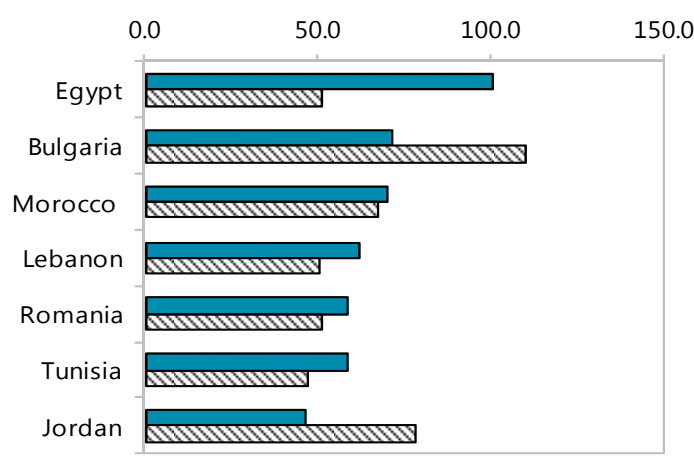

ROE
Lebanon

